\title{
Spatial Distribution of NDVI Trends for Forest Vegetation in the Natural Reserve "Stolby" Based on MODIS Satellite Data
}

\author{
Irina Y. Botvich*, Dmitry V. Emelyanov, \\ Tamara I. Pisman and Anatoly P. Shevyrnogov \\ Institute of Biophysics $S B R A S$ \\ 50/50 Akademgorodok, Krasnoyarsk, 660036, Russia
}

Received 28.10.2019, received in revised form 05.11.2019, accepted 01.12.2019

\begin{abstract}
The purpose of this work is to assess the long-term changes in the state of forest vegetation on the territory of the Nature Reserve "Stolby" for the period 2000-2018. An algorithm has been developed for this and a map of the spatial distribution of the average annual NDVI trends of forest vegetation according to MODIS satellite data has been created (May - September as averaging period). In the work, a map of vegetation cover was used according to the electronic ecological atlas of the Nature Reserve "Stolby". The analysis of the distribution of the number of pixels on the values of the average annual NDVI trend revealed that for the class of coniferous vegetation negative values of the linear trend prevail (by 30\%). For the deciduous vegetation class, the number of pixels with negative values of linear trend slope is $3.1 \%$ higher than with positive ones. In general, for most types of forest vegetation negative trends NDVI prevail. The negative NDVI trend slope of vegetation indicates degradation processes. The reasons for this are the changes of climatic factors, anthropogenic impact, fires, aging and forest vegetation diseases.
\end{abstract}

Keywords: Siberia, the Stolby Nature Reserve, coniferous and deciduous trees, MODIS, NDVI trends.

Citation: Botvich I.Y., Emelyanov D.V., Pisman T.I., Shevyrnogov A.P. Spatial distribution of NDVI trends for forest vegetation in the natural reserve "Stolby" based on MODIS satellite data, J. Sib. Fed. Univ. Eng. technol., 2019, 12(8), 998-1005. DOI: $10.17516 / 1999-494 X-0200$.

(C) Siberian Federal University. All rights reserved

This work is licensed under a Creative Commons Attribution-NonCommercial 4.0 International License (CC BY-NC 4.0).

* Corresponding author E-mail address: irina.pugacheva@mail.ru 


\title{
Пространственное распределение трендов NDVI лесной растительности заповедника «Столбы» по спутниковым данным MODIS
}

\author{
И.Ю. Ботвич, Д.В. Емельянов, \\ Т.И. Письман, А.П. Шевырногов \\ Институт биофизики СО РАН
} Россия, 660036, Красноярск, Академгородок, 50/50

Целью работы является оценка многолетних изменений состояния лесной растительности на территории заповедника «Столбы» за период 2000-2018 г2. Для этого разработан алгоритм и создана карта пространственного распределения среднегодовых трендов NDVI лесной растительности по спутниковым даннымм MODIS (период усреднения май - сентябрь). В работе использована карта растительного покрова по данным электронного экологического атласа заповедника «Столбы». Анализ распределения количества пикселей по значениям среднегодового тренда NDVI выявил, что для класса хвойная растительность преобладают отрицательные значения линейного тренда (на 30 \%). Для класса лиственная растительность количество пикселей с отрицательными значениями уклона линейного тренда на 3.1 \% больще, чем с положительными. В иеелом для большинства видов лесной растительности преобладают отрииательные значения среднегодовых трендов NDVI. Отрииательный уклон тренда NDVI растительности указывает на деградационные проиессы. Причиной этого являются изменения климатических факторов, антропогенное воздействие, пожары, старение и болезни лесной растительности.

Ключевые слова: Сибирь, заповедник «Столбы», хвойные илиственные деревья, MODIS, тренды NDVI.

\section{Introduction}

Forests are the dominant ecosystems of Earth, which are critical to the health of the biosphere. They are the main source of oxygen on the Earth. The state of the forests should be regularly monitored, as they are changing continuously due to influences of natural and human-induced factors such as fires, tree felling, and industrial pollution [1].

Effective management of plant resources is impossible without knowing to what extent external factors, mainly climate and human activities, influence historical dynamics of vegetation [2]. The second most important factor determining interannual variations in plant growth conditions in arid regions is precipitation [3].

It is well-known that forests consisting of different tree species may show different dynamics of phenological development [4]. Classification of forests consisting of several tree species, which differ in their phenological dynamics, can be done by using satellite images taken in different periods of the yearly plant life cycle.

The most widely used index is NDVI (Normalized Difference Vegetation Index) - a simple indicator of the quantity of photosynthetically active biomass [5,6]. Indices of this group quantify the total vegetation, and they are used to estimate its state for solving a wide range of issues.

The main advantages of vegetation indices are that they are easy to derive and that they can be used to solve a wide range of problems. Based on this index, one can obtain numerical data 
to estimate and predict forest stand productivity, biodiversity, the degree of damage done to the forest by various natural and manmade disasters, etc. NDVI is used to reveal zones of suppressed vegetation [7].

In various studies relating to the city of Krasnoyarsk, the Nature Reserve "Stolby" is considered as the reference area, which is unaffected by industrial emissions. Other data, however, suggest that the Reserve is affected by emissions from the stationary sources in Krasnoyarsk. Therefore, it is important to determine the real reasons for changes in the state of forest stands in this region, i.e. to study plant canopy dynamics. Monitoring the ecosystems in conservation areas is restricted by environmental regulations. Thus, remote sensing techniques are the methods of choice in studying various environmental parameters and indicating the state of the environment in the regions with limited use of natural resources [8].

The purpose of this work is to assess the long-term changes in the state of forest vegetation on the territory of the Nature Reserve "Stolby" for the period 2000-2018. An algorithm has been developed for this and a map of the spatial distribution of the average annual NDVI trends of forest vegetation according to MODIS satellite data has been created.

\section{Material and methods}

Forest stands located in the Nature Reserve "Stolby" (40 km away from Krasnoyarsk, $\left(55^{\circ} 38^{\prime}-\right.$ $55^{\circ} 55^{\prime} \mathrm{N}, 92^{\circ} 35^{\prime}-93^{\circ} 10^{\prime}$ E) were used as study sites. The forest sites investigated in this study comprised the following major tree species: deciduous trees - silver birch (Betula pendula) and aspen (Populus tremula), and conifers - Scots pine (Pinus silvestris), Siberian fir (Abies sibirica), Siberian spruce (Picea obovata), Siberian pine (Pinus sibirica) and Siberian larch (Larix sibirica).

In the work, a map of vegetation cover was used according to the electronic ecological atlas of the Nature Reserve "Stolby" [9]. The ecological atlas is a web-based set of thematic electronic maps, built on the basis of geoinformation analysis, generalization and interpretation of research results on the ecosystem of the Nature Reserve "Stolby" territory. The thematic maps have been received by Erunova M.G. as a result of interpolation, according to observations of a researcher of the Nature Reserve "Stolby" R.A. Kolovsky [10]. The model of the Nature Reserve territory comprises more than 50 thematic maps, including a map of vegetation cover.

The construction of spatial distribution of linear NDVI trends of forest vegetation of the Nature Reserve "Stolby" was performed according to the algorithm represented in the form of a flowchart in Fig. 1.

Algorithm for map construction of spatial distribution of NDVI trend values according to Modis spectroradiometers of Terra and Aqua satellites includes the following steps:

1. There is a MOD09Q1 and MYD09Q1 product data archive forming during the vegetation periods in 2000-2018 (http://modis.gsfc.nasa.gov/).

2. By means of MODIS Reprojection Tool Software the transformation of the projection data from Sinusoidal projection in Universal Transverse Mercator (UTM) is made.

3. Channel values of band $1(620-670 \mathrm{~nm})$ and band $2(841-876 \mathrm{~nm})$ are used for NDVI calculation.

$$
N D V I=\frac{b 2-b 1}{b 2+b 1}
$$




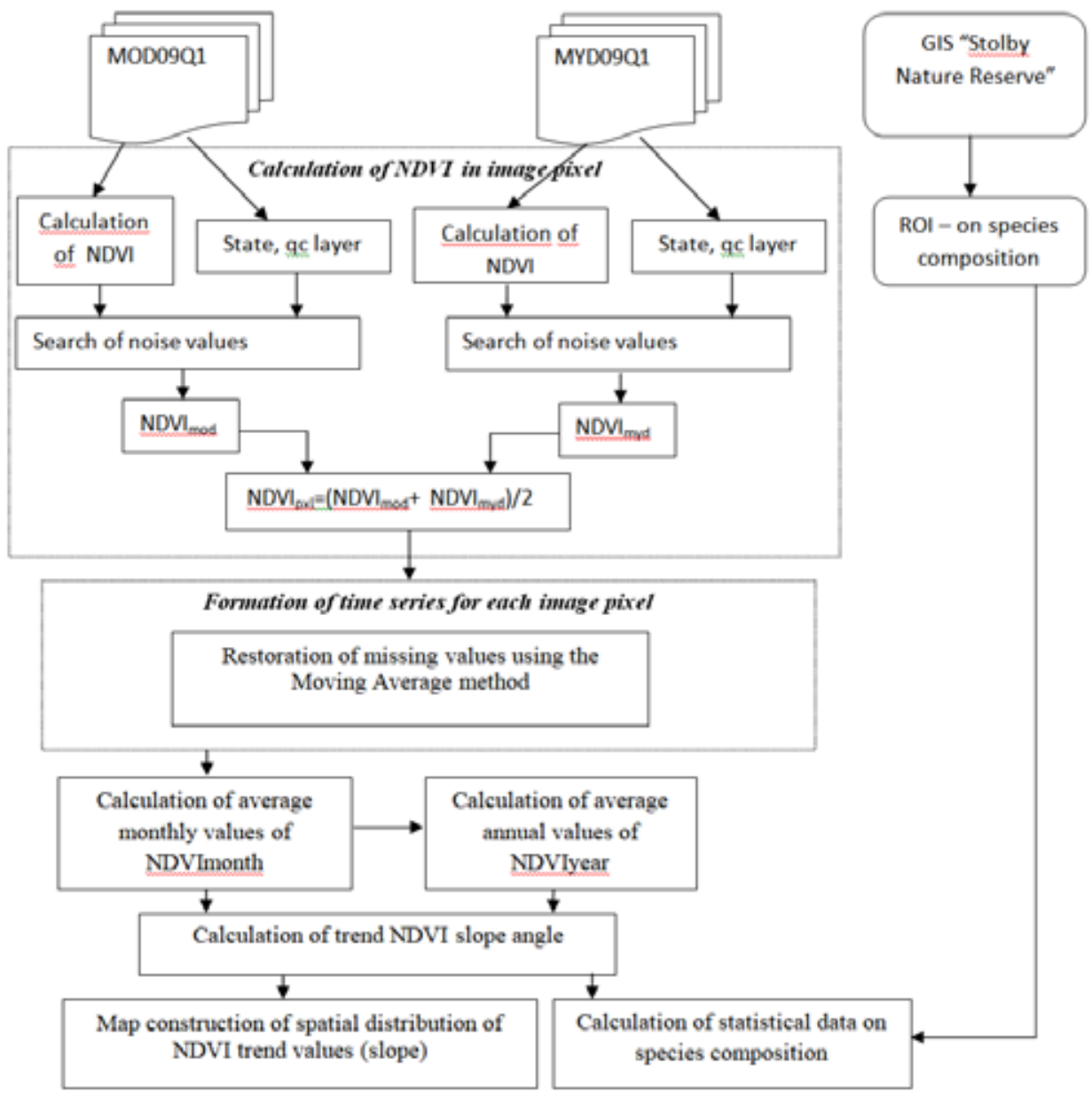

Fig. 1. Flowchart of the data processing algorithm

4. NDVI values calculated from MODIS spectroradiometers of Terra and Aqua satellites are averaged taking into account the information of the layers "sur_refl_state_250m" and "sur_refl_ qc_250m":

$$
N D V I_{p x l}=\left(N D V I_{m o d}+N D V I_{m y d}\right) / 2 .
$$

5. For each pixel with coordinates ( $\mathrm{x}, \mathrm{y})$ of satellite image, time series $\mathrm{Y}=\left\{\mathrm{y}_{1}, \mathrm{y}_{2}, \ldots, \mathrm{y}_{\mathrm{n}}\right\}$ of NDVI values is formed. The row is temporarily formed from the measurements $\mathrm{y}_{\mathrm{i}}$, including the noise values obtained at the respective moments in time ti.

6. Noise values in the time series are marked by a special flag and are not used. These values are replaced by the average of the previous and next values of the vegetation index (calculation of the average with the size of the sliding window equal to 3 ).

$$
y_{i}=\frac{y_{i-1}+y_{i+1}}{2} .
$$

If two values are missing in a row, the average value of the sliding window with a width of 5 is assigned to the value of this pixel, while the noise values are not used. 
7. Then the calculation of the average monthly values of $\mathrm{NDVI}_{\text {month }}$ and the average annual values of $\mathrm{NDVI}_{\text {year }}$ (May-September as averaging period) is made.

8. The obtained data are the basis for the linear regression model construction and the angular coefficient (trend) determination. The significance level is calculated (a trend with a $95 \%$ level is considered significant $(\mathrm{p}<0.05))$.

9. When creating the map of the spatial distribution of linear trend values, "Decision Tree" classification type is used which allows to set gradations of trend values and according to them choose color mapping. Forty-five classes are selected with a trend value step of 0.001 , color gradation from red to blue.

The calculation of the statistical data on species composition is made using GIS vector data of the Nature Reserve "Stolby". A separate ROI (Region of Interest) layer is formed for each species, and the quantity of positive and negative trends is calculated.

\section{Results and discussion}

The national Nature Reserve "Stolby" was founded in 1925 on the initiative of citizens of the city to preserve natural complexes around the picturesque syenitic remains - "pillars". The territory of the Nature Reserve, before the introduction of the reserve regime, was subjected to significant anthropogenic impact. This caused the appearance of broadleaved species on a large area. Compliance of the reserve regime contributed to an increase in the proportion of pine (from $40 \%$ in 1959 to $45 \%$ in 2007) and fir (from $24 \%$ in 1959 to $29 \%$ in 2007). The greatest changes are observed for the area occupied by soft-leaved stands (birch, aspen): it decreased by $8 \%$ (of the entire forested area) [11].

Since the beginning of 2000s, the dynamics of massive drying of fir stands in the mountain forests of the Eastern Sayan (Nature Reserve "Stolby") has been recorded. The fir drying has been provoked by water stress caused by air temperature increase simultaneously with the influence of the Ussuri bark beetle (Polygraphus proximus Blandford), xylophage [12].

For the analysis of the spatio-temporal changes in forest vegetation of the Nature Reserve "Stolby" over the last 19 years, a map of the spatial distribution of linear average annual trends NDVI year $_{\text {(May - }}$ September as averaging period) has been constructed (Fig. 2).

The analysis of the distribution of the number of pixels on the values of the average annual NDVIyear trend revealed that for the class of coniferous vegetation negative values of the linear trend prevail (by 30\%) (Fig. 2). For the deciduous vegetation class, the number of pixels with negative values of linear trend slope is $3.1 \%$ higher than with positive ones. In general, for most types of forest vegetation negative trends $\mathrm{NDVI}_{\text {year }}$ prevail. It was found that for the species Siberian cedar "Pinus sibirica" and Siberian fir "Abies sibirica" the number of pixels with a negative trend slope $-97.5 \%$ and $91.4 \%$ respectively prevail significantly. For species aspen "Populus tremula" and birch "Betula pendula" the number of pixels with a negative trend slope prevails slightly. The predominance of the number of pixels with a positive slope of the linear trend $\mathrm{NDVI}_{\text {year }}$ is typically for the species common pine "Pinus silvestris "(Fig. 3).

The obtained maps of the spatial distribution of linear trends of the average annual NDVI confirmed the basic tendencies found during the complex analysis of the data on the Nature Reserve forestry inventories $[11,12]$. 


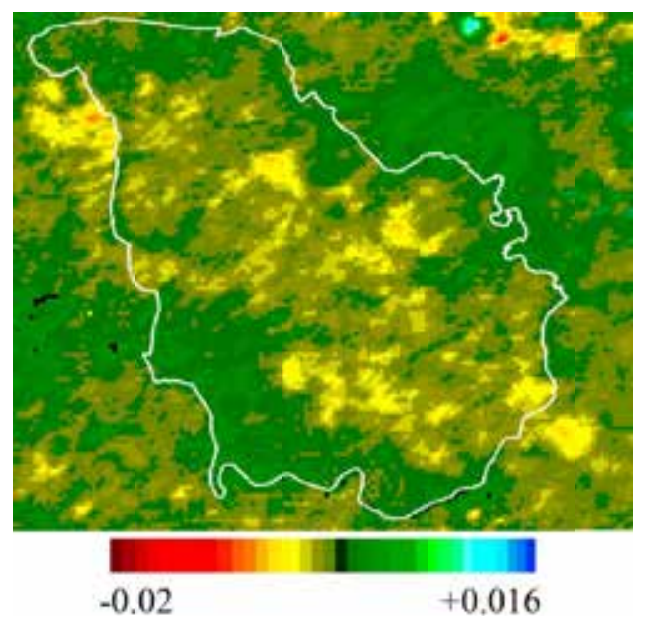

Fig. 2. The spatial distribution of average annual trends NDVIyear (May - September as averaging period) of forest vegetation on the territory of the Nature Reserve "Stolby" for the period 2000-2018

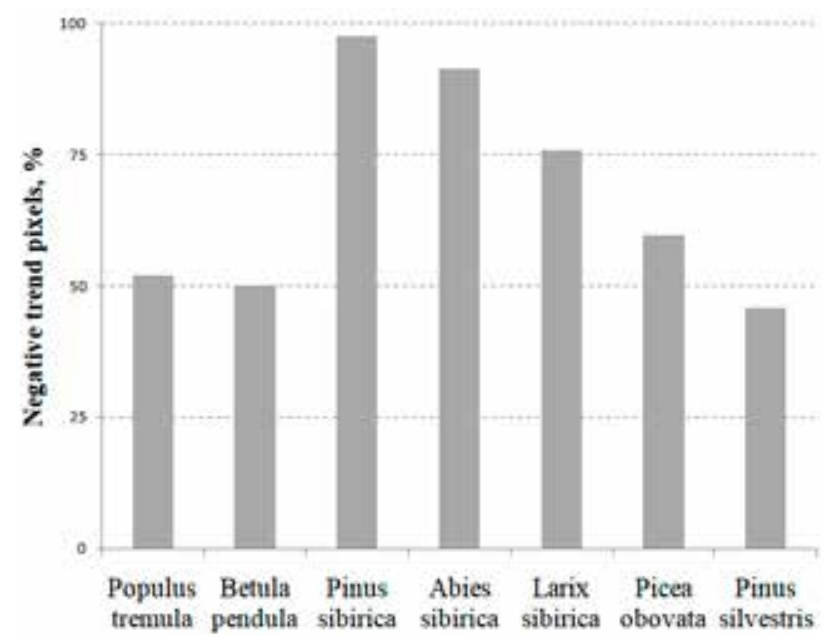

Fig. 3. Negative trend pixels for each tree species

\section{Conclusion}

The algorithm of evaluation of long-term dynamics of forest vegetation state of the Nature Reserve "Stolby" for the period 2000 - 2018 according to MODIS satellite data has been developed. On the basis of the linear trends of average annual NDVI $\mathrm{I}_{\text {year }}$ analysis of different wood species, it was found that the character of NDVI $_{\text {year }}$ trends is multidirectional. At the same time, the number of pixels with a negative trend surpasses the number of pixels with a positive trend 1.7 times (63.6\% - with a negative trend, $36.4 \%$ - with a positive trend). The positive trends $\mathrm{NDVI}_{\text {year }}$ refer mainly to the species common pine (Scots pine), negative - to the rest of the coniferous and deciduous stands.

The negative NDVI trend slope of vegetation indicates degradation processes. The reasons for this are the changes of climatic factors, anthropogenic impact, fires, aging and forest vegetation diseases. 
The reported study was funded by Russian Foundation for Basic Research, Government of Krasnoyarsk Territory, Krasnoyarsk Regional Fund of Science to the research project №. 18-45243007 and was supported by the State budget allocated to the fundamental research at the Russian Academy of Sciences (project No. AAAA-A17-117013050027-1).

\section{References}

[1] Cuevas-Gonzalez M., Balzter H., Gerard F.F., Piano D. Analysing forest recovery after wildfire disturbance in boreal Siberia using remotely sensed vegetation indices. Global Change Biology, 2009, $15,561-577$.

[2] Walther G.R., Pos E., Convey P., Menzel A., Parmesan C., Beebee T.J., Fromentin J.M., Hoegh - Guldberg O., Bairlein F. Ecological responses to recent climate change. Nature, 2002, 416, 389-395.

[3] Fabricante I.M., Oesterheld J.M.P. Annual and seasonal variation of NDVI explained by current and previous precipitation across Northern Patagonia. Journal of Arid Environments, 2009, $73,745-753$.

[4] Xiao J., Moody A. Trends in vegetation activity and their climatic correlates: China 1982 to 1998. Int. J. Remote Sensing, 2004, 25, 5669-5689.

[5] Kowabata A., Ichi K., Yamaguchi Y. Global Monitoring of Interannual Changes in Vegetation Activities Using NDVI and its Relationship to Temperature and Precipitation. Int. J. Remote Sensing, 2001, 22, 1377-1382.

[6] Kouadio L., Newlands N.K., Davidson A., Zhang Y. and Chipanshi A. Assessing the Performance of MODIS NDVI and EVI for Seasonal Crop Yield Forecasting at the Ecodistrict Scale. Remote Sens., 2014, 6(10), 10193-10214. DOI: 10.3390/rs61010193.

[7] Heiskanen J. Estimating aboveground tree biomass and leaf area index in a mountain birch forest using ASTER satellite data. Int. J. Remote Sens., 2006, 27, 1135-1158.

[8] Brice S.E., Constant H., Michel B. NDVI sensibility to rainfall spatial distribution in Adjohoun (Benin, west Africa). International Journal of Current Engineering and Technology, 2015, 5(1), 269273.

[9] Экологический атлас заповедника «Столбы», http://stolby.torins.ru [Ecological atlas of Nature Reserve "Stolby" (in Russian)]

[10] Гостева А.А., Ерунова М.Г., Савченко А.П. Геоинформационное картографирование динамики формационного состава лесов территории заповедника “Столбы”. Материаль Международной конференции “ИнтерКарто. ИнтерГИС”, 2018, 24(1), 475-484. http:// doi.org/10.24057/2414-9179-2018-1-24-475-484 [Gosteva A.A., Erunova M.G., Savchenko A.P. Geoinformation mapping of the dynamics of the forest formation composition at the Stolby restricted nature reserves. Materialy Mezhdunarodnoj konferencii "InterKarto. InterGIS" (Proceedings of the International conference "InterCarto. InterGIS"), 2018, 24(1), 475-484 (In Russian)]

[11] Шушпанов А.С., Кузьмичев В.В. Динамика горных лесов на охраняемой территории (заповедник “Столбы”). Научный журнал КубГАУ, 2013, 91(07), 314-324 [Shushpanov A.S., Kuzmichev V.V., Shushpanov A.S., Kuzmichev V.V. Dynamics of mountain forests on the protected territory (nature reserve "Stolby"). Nauchnyj zhurnal KubGAU (Scientific journal KubSAU), 2013, 91(07), 314 -324 (In Russian)] 
[12] Харук В.И., Шушпанов А.С., Петров И.А., Демидко Д.А., Им С.Т., Кнорре А.А. Усыхание Abies sibirica Ledeb. В горных лесах Восточного Саяна. Сибирский экологический журнал, 2019, 26(4), 369-382 [Kharuk V.I., Shushpanov A.S., Petrov I.A., Demidko D.A., Im S.T., Knorre A.A. Drying of Abies sibirica Ledeb. in mountain forests of the Eastern Sayan. Sibirskij ekologicheskij zhurnal (Siberian ecological journal), 2019, 26(4), 369-382 (In Russian)] 